\title{
A Relação Mãe-Bebê e a Estruturação da Personalidade
}

\section{Affective Interaction Mother-Infant and the Personality Formation}

Rubens de Aguiar Maciel

Psicólogo, Mestre em Saúde Pública pela Faculdade de Saúde

Pública da Universidade de São Paulo

E-mail: rubensmळusp.br

Coronélio Pedroso Rosemburg

Professor Associado da Faculdade de Saúde Pública da Universi-

dade de São Paulo

\section{Resumo}

Este artigo é resultado da dissertação de mestrado,na qual foi feita uma reflexão sobre a construção da personalidade a partir do desejo de compreender melhor a população de jovens em situação de rua. Foi, realizada uma leitura psicanalítica do problema, a qual postula que a interação afetiva entre a mãe e o bebê tem papel fundamental na construção da personalidade.

Partiu-se da hipótese de que a personalidade de jovens provenientes de famílias carentes pode começar a ser comprometida logo em seu primeiro ano de vida, considerando os fatores estressantes e desestabilizadores das condições emocionais em que vivem essas famílias. Foram encontrados jovens, a maioria envolvida com drogas e com o crime, que se desenvolveram em famílias desestruturadas e em condições bem adversas. Propõem-se que políticas públicas sejam desenvolvidas para a família de gestantes e após o nascimento até o primeiro ano de vida, visando oferecer suporte para melhorar as condições emocionais dos pais, o que proporcionaria melhores condições para a estruturação da personalidade de seus filhos.

Palavras-chave: Personalidade; Psicanálise; Relações sociais; Saúde Pública. 


\section{Abstract}

This paper is the result of a Masters' thesis in which we conduct an analysis of personality formation with the goal of better understanding the situation of children living on the streets. We have looked at the problem from a psychoanalytical perspective, which postulates that the affective interaction between mother and infant plays a fundamental role in personality formation. Our hypothesis is that the personality of youngsters from underprivileged families can be compromised even in their first year of life, taking into account the stressing and destabilizing factors in these families' emotional conditions. We have identified youngsters, most of them involved with drugs and crime, raised in unstructured families in quite adverse conditions. We propose public policies for families with pregnant women, as well as for those with infants in their first year, that aim at providing better support for parents' emotional conditions, which in their turn provide better conditions for their children's personality formation.

Keywords: Personality; Psychoanalysis; Social Relations; Public Health.

\section{Introdução}

Este trabalho teve por objetivo, compreender melhor as condições de desenvolvimento da personalidade de jovens que viveram nas ruas, consumindo drogas, praticando delitos. A pobreza e a falta de oportunidades não explicam totalmente a escolha de uma vida marginal, embora tenham papel muito significativo. Isso fica mais claro quando observamos que da mesma família surgem jovens que seguem caminhos quase opostos. Abandonar ou ser abandonado pela família, viver circulando entre sua família e outros espaços, utilizar drogas, envolver-se com o crime, ou desenvolver uma estrutura emocional frágil e imatura é algo que pode acontecer com qualquer sujeito, independente de sua classe social, sua condição cultural, educacional ou religiosa. Fica a pergunta: o que ocorreu de diferente para produzir esse resultado?

A teoria psicanalítica propõe como base fundamental para a estruturação da personalidade de um indivíduo principalmente a qualidade da interação entre o recém-nascido e sua mãe. A ausência de pai, mãe, figuras cuidadoras constantes podem promover dificuldades na formação da personalidade. Uma mãe suficientemente equilibrada e amadurecida é essencial para atender as necessidades físicas e emocionais de seu bebê e, auxiliá-lo na construção de sua personalidade.

Ao escolhermos a população de estudo, consideramos que os jovens encontrados nos abrigos, provavelmente, teriam vindo das classes sociais menos favorecidas e essa condição nos seria relevante por supormos que as circunstâncias de desenvolvimento desses sujeitos, se deram em condições menos privilegiadas, mais desprotegidas, inseguras, instáveis, isto é, potencialmente mais desfavoráveis, o que, em tese, reproduziria o cenário inicial que desejávamos para investigar: os efeitos decorrentes das circunstâncias inadequadas para o desenvolvimento. Procuramos, então, compreender, em que condições de vida viviam seus pais na época de seus nascimentos e como se desenvolveram emocionalmente esses jovens.

Entrevistamos e testamos cinco jovens, três homens e duas mulheres, que viveram nas ruas, com várias passagens por outros abrigos ou pela Febem (Fundação do Bem-Estar do Menor). Eles estavam temporariamente abrigados em instituições mantidas pela Igreja e pela sociedade civil, respectivamente Associa- 
ção Marly Cury e o Centro de Convivência Nossa Senhora do Bom Parto.

Essa investigação foi aprovada pelo Comitê de Ética da Comissão de Pós-Graduação da Faculdade de Saúde Pública da Universidade de São Paulo e o Termo de Responsabilidade do pesquisador foi encaminhado para a diretoria das instituições Atendendo às exigências da Resolução CNS 196/96, que assegura a responsabilidade do pesquisador quando da necessidade de pesquisa com seres humanos, foi solicitado previamente o consentimento livre e esclarecido dos sujeitos da pesquisa.

A vida do homem contemporâneo sofreu, transformações significativas, como: novas formas de composição familiar, que atualmente é reduzida em número de filhos e agregados, como parentes e vizinhança -, aumento das separações entre os casais que levam os filhos a morar com um dos pais ou com o novo parceiro de um de seus pais -, aumento de mães solteiras, que, muitas vezes, encarregam-se do sustento da família e os novos papéis atribuídos aos avós.

Por outro lado, o psicanalista Calligaris (2004) percorre as mudanças de pensamento dentro do campo da psicologia e relembra que, quatro décadas atrás, a família era vista como o "berço da loucura”, um refinado instrumento de domínio, que subjugava os jovens às normas vigentes. Naquela época, também, tomou força um movimento que procurava desmontar os esquemas de confinamento dos pacientes psiquiátricos e devolvê-los à família e à sociedade. Estava criado o problema, devolver o doente mental à fábrica de loucura (a família). Atualmente, o que encontramos é uma bibliografia que valoriza a família, a qual, devidamente instruída, torne-se a terapeuta de seus membros doentes.

\section{Aportes da Teoria Psicanalítica}

Conforme dito anteriormente, neste trabalho procuramos abordar o que há de mais básico quando pensa- mos sobre o comportamento dos seres humanos: sua personalidade (in: Rappaport, 2003). A condição de desamparo em que o recém-nascido chega ao mundo estabelece uma necessária relação de dependência com sua mãe. Devido a esse tipo de relação, necessária no início da vida, o bebê é intensamente afetado na construção de sua personalidade pela natureza dos laços maternos. A mãe, por sua vez, tem sua disponibilidade afetiva, ou seja, seu equilíbrio emocional afetado, por uma extensa rede de influências internas e externas que influenciam positiva ou negativamente suas condições de maternagem.

Sobre o comportamento social dos indivíduos, Klein (1971, p. 1) escreve:

Ao considerar, do ponto de vista psicanalítico, o comportamento das pessoas no seu ambiente social, é necessário investigar como o indivíduo se desenvolve desde a infância até a maturidade.

Um grupo - seja pequeno ou grande - consta de indivíduos num relacionamento recíproco; $e$, portanto, a compreensão da personalidade é o fundamento para compreender a vida social.

Sabemos que logo ao nascer, a criança precisa de cuidados intensos e, de proteção e gratificação, devido à sua condição de desamparo mental e biológico, quase como um prolongamento do estado anterior, porém fora do útero. A mãe que originalmente satisfez todas as necessidades do feto através de seu corpo, continua a fazê-lo após o seu nascimento, embora parcialmente por outros meios (Brenner, 1975).

Em Inibição, sintoma e angustia, Freud (1976) escreveu: "O que acontece é que a situação biológica da criança, como feto, é substituída para ela por uma relação de objeto² psíquico com sua mãe" (p. 162). E ainda: "Essa condição de extrema e prolongada dependência é determinante na formação da personalidade do ser humano" (p. 163).

Assim, a relação de apoio em um cuidador torna esse adulto o representante externo da satisfação do

\footnotetext{
1 Segundo Reis (2003), personalidade pode ser descrita pelos sistemas tópico, dinâmico e econômico e a perspectiva genética. 0 sistema tópico é constituído pelo inconsciente, o pré-consciente e o consciente; o sistema dinâmico, por sua vez, é composto de id, ego e superego; o sistema econômico, ressalta o fato de que quantidades de energia de cada um dos processos (primário e secundário) são distribuídas de maneira distintas. A perspectiva genética mostra que a personalidade se constrói por meio de caminhos e descaminhos do desejo, o que significa dizer que é pela nossa história de vida que forjamos nossa personalidade.

2 Objeto possui em psicanálise uma conotação diferenciada. Esse termo pode referir-se a uma pessoa ou a algo inanimado e diz respeito a algo que é visado pelas pulsões psicologicamente significantes. Não há aqui um sentido pejorativo ou desumanizante. As pulsões “escolhem um objeto" de "amor ou ódio", para realizar sua finalidade, que é a sua satisfação. (Laplanche e Pontalis, 1970, p. 407).
} 
bebê, fazendo com que o cuidador seja investido de energia libidinal, isto é, de interesse, de importância, de amor. A sensação de grande tensão e desconforto, provocada pela fome, por exemplo, que nos primeiros momentos de vida era sentida como perigosa, gerando ansiedade, desloca-se agora para o medo da perda do objeto de amor, isto é, daquele que supre prontamente às necessidades do recém-nascido. Quem vê um bebê, sendo amamentado percebe claramente a sensação de prazer e relaxamento de que ele desfruta. 0 recém-nascido, que inicialmente está totalmente voltado para si mesmo, se apóia no prazer que ele recebe de sua mãe, para começar a investir seu interesse em uma outra pessoa, no caso a mãe (libido objetal). Essas experiências, de necessitar de alguém e o medo de perdê-lo, vão acompanhar o indivíduo por toda a sua vida (Freud, 1976).

Klein (1982), que nomeia este vínculo de "Relações de Objeto"3, aprofunda seus estudos e enfatiza sua importância para a construção da personalidade: as relações entre o bebê e sua mãe, construídas principalmente no primeiro ano de vida, período de extrema plasticidade do recém-nascido, acabam estabelecendo desde muito cedo o modelo básico de como ele se relacionará consigo mesmo e com os outros, durante a sua vida. Esse modelo básico o acompanhará sem grandes mudanças, na maioria dos casos, até a vida adulta, embora ele possa viver experiências que tragam enriquecimento e progresso pessoal.

No principio, a criança não tem noção da realidade exterior, o mundo é ela própria, envolvida com suas sensações e emoções. Quando as experiências de frustração e ansiedade vão sendo repetidamente aliviadas por alguém, elas permitem à criança ter noção de uma realidade externa, inicialmente representada pelo seio de sua mãe. Depois, ela vai progressivamente percebendo o outro de maneira parcial, primeiramente o seio, o cheiro, a voz, até finalmente formar a noção de uma pessoa total Na relação de aleitamento, o bebê vai introjetando 4 a disposição afetiva da mãe em relação a ele, e, assim, vai criando internamente uma representação mental daquele “objeto". A mãe vai fornecendo maior ou menor quantidade de libido (afeto, desejo, interesse, ansiedade, medo, rejeição) e este é um fator crucial no desenvolvimento do indivíduo.

0 estresse provocado pelo estado de frustração pode gerar no bebê um intenso sentimento de ódio, vivido como uma ameaça terrorífica à sobrevivência, sob a forma de temor de aniquilamento. Quando a quantidade de frustração é demasiadamente intensa para o bebê, entra em ação um mecanismo mental rudimentar, primitivo, mediante ao qual a criança projeta 5 para fora de si e "coloca" no seio da mãe todos aqueles conteúdos agressivos, dos quais ela precisa se livrar, pois não consegue senti-los como algo próprio. 0 ódio passa, então, a ser concebido como vindo de fora, tornando-se o seio materno um objeto de perseguição que gera na criança um temor de ser destruída por um seio mau e perseguidor. Caso a mãe se sinta muito angustiada com as reações do bebê e não seja capaz de digerir internamente toda a angústia e raiva que o bebê projeta sobre ela, acaba interagindo com a criança em um estado ansioso, carregado de sentimentos ambivalentes, de insegurança e raiva, provocando no bebê a fantasia ${ }^{6}$ inconsciente de que ele é possuidor de elementos muito destrutivos e, aquele seio, ob-

3 Relação de objeto, ou objetal, designa o modo de relação do indivíduo com o seu mundo, que é o resultado complexo e total de uma determinada organização da personalidade, de uma apreensão mais ou menos fantasmática dos objetos e de certos tipos privilegiados de defesa. (Laplanche e Pontalis, 1970, p. 576).

4 Atividade defensiva pela qual o aparelho psíquico normal assimilaria atributos e qualidades de objetos externos ao ego: pessoas, coisas, animais. ,(Almeida, W. C., 1996, p. 62)

5 (....) a projeção se dá sobre pessoas e coisas e o material projetado poderá ser: qualidades, sentimentos e desejos. Com a característica de que este material estará sendo recusado ou desconhecido pelo sujeito que o projeta, em função do desconforto psíquico e da ansiedade gerada, em plano inconsciente (Almeida, W. C., 1996, p. 59).

6 A psicanalista Susan Isaacs nos fornece uma noção bastante aprofundada do conceito de fantasia em seu artigo "A Natureza e a Função da Fantasia”, capítulo do livro Progressos da Psicanálise. Para a psicanálise a idéia de fantasia difere daquela aceita no sentido laico onde é utilizada para assinalar o contraste com a realidade, que aqui assume uma acepção que a torna idêntica a fatos "externos", “materiais" ou “objetivos". Quando falamos de realidade "externa”, “objetiva”, podemos estabelecer um pressuposto que nega à realidade psíquica sua própria objetividade como fato mental, atitude que deprecia a realidade psíquica. A fantasia é uma atividade inconsciente e tem inicio já nos primeiros meses de vida da criança, antes mesmo da formação da linguagem. 0 inconsciente possui uma realidade contínua e viva que lhe é própria, com suas leis e características dinâmicas, diferentes do mundo externo. Todos os processos mentais originam-se no inconsciente e só sob certas condições tornam-se conscientes. 
jeto de tal ódio, torna-se um objeto com conteúdos maléficos e poderes de destruição. Nessas condições, o $\mathrm{ego}^{7}$ do bebê não pode se desenvolver adequadamente e a criança sentirá o mundo como um lugar hostil, que não tolera suas angústias, sua raiva ou, ela mesma, como um todo.

A experiência de ser alimentado, acariciado, olhado nos olhos e de ouvir as palavras carinhosas da mãe gera no bebê a vivência de um seio bom, gratificador, que faz com que ele tenha a experiência de algo externo bom, assegurador, tranqüilizante. Quando a mãe é capaz de perceber as angústias de seu filho, pode tolerá-las e metabolizá-las emocionalmente, para, em seguida, aplacar seus medos, tranqüilizando-o; assim, ela vai reafirmando para ele a confiança no mundo (interno e externo) como um lugar em ele que se desenvolver (Soifer, 1992).

Quando o recém-nascido sente que seu ódio pode ser acolhido, compreendido, e que sua mãe pode manter seu afeto e continuar cuidando dele, ele pode passar para um outro modo de conceber o mundo e de se relacionar com ele. Nessa outra maneira de atribuir significado à experiência, há o reconhecimento da destrutividade como própria e, portanto, dos danos que ela pode causar ao objeto, havendo maior consciência da separação entre sujeito e objeto. A consciência da destrutividade como parte do próprio bebê desperta nele culpa e remorso, e a atitude predominante é a de procurar reparar ${ }^{8}$ os danos causados, buscando dessa maneira evitar a perda ou destruição do objeto concebido como satisfatório.

Em uma família a interação afetiva é bastante operante (mesmo naquelas em que observamos aparente frieza e distanciamento), tendo importantes reflexos sobre o mundo interno de seus membros, principalmente no das crianças. Circunstâncias adversas dentro da família podem estabelecer em um ou mais dos seus membros desequilíbrios emocionais agudos e, dependendo da intensidade do estímulo, do tempo de duração da adversidade e as características pessoais do indivíduo, esses desequilíbrios podem vir a se tornar crônicos. Em geral, as crianças e as personalidades mais frágeis são as que sofrem os maiores agravos. Para uma criança pequena, que possui um aparelho psíquico ainda em desenvolvimento, circunstâncias persistentes de extrema frustração e estresse podem afetar mais marcadamente a constituição de sua personalidade.

É fundamental considerar a ressalva de Klein (1971, p. 258) ao afirmar que:

Mesmo o bom efeito da criação nos primeiros tempos pode ser, em certa medida, anulado através de ulteriores experiências prejudiciais e maléficas, assim como as dificuldades surgidas no começo da vida podem ser mitigadas através de subseqüentes experiências benéficas. Ao mesmo tempo, convém recordar que algumas crianças parecem recordar condições externas desfavoráveis sem grande dano para seu caráter e estabilidade mental, ao passo que em outras, apesar de um ambiente favorável, manifestam (....) sérias dificuldades

\section{Método}

Adotamos o método qualitativo, pois a natureza das informações que procuramos é da ordem do subjetivo e, para isso, o pesquisador precisa penetrar no mundo dos significados que o sujeito atribui à vida.

Entrevistamos cinco jovens entre 15 e 19 anos, dois do sexo feminino e três do sexo masculino. Quatro sujeitos estavam abrigados na Associação Marly Cury (AMC) e o quinto (masculino), foi entrevistado no Espaço de Convivência Nossa Senhora do Bom Parto.

Os sujeitos foram escolhidos por estarem abrigados em instituições, situação favorável para serem reencontrados e assim, darmos continuidade à investigação.

\footnotetext{
7 Instância que Freud distingue do id e do superego. Do ponto de vista tópico, o ego está em uma relação de dependência quanto às reivindicações do id, bem como aos imperativos do superego e às exigências da realidade. Do ponto de vista dinâmico, o ego representa, eminentemente, no conflito neurótico, o pólo defensivo da personalidade; põe em jogo uma série de mecanismos de defesa. Do ponto de vista econômico, o ego surge como um fator de ligação dos processos psíquicos. A teoria psicanalítica procura explicar a gênese do ego em dois registros, relativamente heterogêneos, quer vendo nele um aparelho adaptativo, diferenciado a partir do id, em contato com a realidade exterior, quer definindo-o como o produto de identificações que levam a formação no seio da pessoa de um amor investido pelo id. (Laplanche e Pontalis, 1970, p. 172)

8 Em linguagem simples e popular, reparação é a capacidade de pedir desculpas e arrepender-se por atos sacados contra terceiros e socialmente ou moralmente condenados. Também é saber ser grato (Almeida, 1996, p. 69)
} 
Isso seria quase impossível com jovens que estivessem morando nas ruas e se deslocando com freqüência.

Para a coleta dos dados narrados, utilizamos o tipo de entrevista denominado "Depoimento Pessoal" em que o entrevistador conduz o entrevistado para o enfoque desejado, deixando-o livre em seu discurso, dentro dos parâmetros de interesse da pesquisa.

Aplicamos também instrumentos de pesquisa de dados projetivos, que neste estudo está fundamentado nos pressupostos apontados por Silva (1989), no seguinte sentido: “a expressão 'métodos projetivos' (...) enfatiza os aspectos qualitativos e psicológicos, em oposição à tradição psicométrica, a qual visava uma classificação com procedimentos basicamente quantitativos e normativos".

Utilizamos os seguintes instrumentos para a obtenção dos dados subjetivos dos sujeitos: uma entrevista dirigida; dois desenhos livres; o House, Tree and Person (HTP), de John Buck, e o Teste de A percepção Temática (TAT), de Morgan e Murray.

\section{Resultados Obtidos}

O sujeito Pm. ${ }^{9}$, nasceu em Osasco (município de São Paulo), em 1984. Seu pai foi preso pouco antes de ele nascer. Ele morava com sua mãe, C, e duas irmãs, C1., oito anos mais velha, e $\mathrm{P}$, quatro anos mais velha. Sua mãe, $\mathrm{C}$ deu a luz à $\mathrm{P}$ aos vinte e dois anos. Sua primeira filha nasceu, quando ela tinha catorze anos de idade.

Pm. conta que se dava bem com sua irmã mais velha - ela tomava conta dos irmãos quando a mãe saía para trabalhar -, mas não muito com a do meio, pois ela "era muito briguenta".

A mãe abandonou os filhos para ir morar com um namorado quando Pm. tinha dois anos de idade. Passaram-se "dois ou três meses" até que sua tia, C2, levou-os para morar na casa dela. Essa tia bebia e na casa dela havia muitas brigas, fazendo com que as pessoas ficassem longo tempo sem conversar.

Em 1987, Pm. foi morar em Osasco, com sua avó paterna, onde ficou por dois anos. Nessa época, seu tio, J, irmão de seu pai, representou um papel muito importante na sua vida: "como se fosse uma figura paterna”.
Pm foi visitar seu pai na prisão duas vezes, antes de completar três anos de idade. Da primeira visita, ele guardou a forte recordação de quando seu pai levantou-o nos braços e disse aos amigos: "Este aqui é o meu filho!”. Pm. acredita que, se seu pai não tivesse morrido, a família teria se mantido unida. Em 1987, ainda na prisão, o pai de Pm. faleceu, aos trinta anos, vitima de doença cardíaca.

Em 1989, mudou-se para Catanduva (SP) com sua avó e um casal de tios, que logo voltaram para São Paulo, ficando apenas ele e sua avó no local. Sua avó defendia-o de tudo, ele relatou gostar bastante dela.

Em 1993, sua avó faleceu e Pm veio morar em São Paulo, com sua tia, C2. Foi quando reencontrou suas irmãs. Sua irmã do meio saiu de casa quatro ou cinco meses depois de ele ter chegado, e depois disso ele não teve mais notícias dela.

Segundo Pm, sua tia se preocupava muito com suas companhias e o cobrava muito; queria que ele estudasse, trabalhasse, aprendesse a cozinhar, a lavar, a passar, ou seja, que ele seguisse o lado honesto da vida. Sua relação com o tio era distante.

Pm trabalhava na feira. Acordava cedo e depois do trabalho voltava correndo para ir à escola, à tarde. Ele afirmou que não gostava muito de estudar.

Sua saída de casa foi repentina: certo dia de 1995, quando tinha onze anos, ele resolveu dormir na rua, com a intenção de voltar alguns dias depois; queria apenas ficar sozinho. Foi para a região de Pinheiros (bairro de São Paulo), que ele conhecia por causa do trabalho em feiras livres, e passou a tomar conta de carros. Foi ficando e não voltou mais para a casa de sua tia. Disse que a rua o fez aprender a lutar para sobreviver, a se impor diante das situações e a "exercer autoridade nas suas palavras”. Na época, havia regras entre os meninos de rua de Pinheiros: eles não podiam roubar nas imediações e deviam relacionarse bem com a vizinhança.

Seu envolvimento com droga foi pequeno. Teve uma relação estressante e perigosa com os policiais, entretanto, nunca foi preso. Ter visto seus conhecidos serem presos e outros se envolvendo com drogas levou-o a reconsiderar seu modo de vida.

Passou por várias instituições chegando à $\mathrm{AMC}$ em março de 2001, logo na abertura da casa. Disse que a

9 As letras m e f que acompanham as iniciais dos sujeitos designam masculino e feminino. 
diferença da AMC é o interesse que a educadora $\mathrm{M} \mathrm{e} \mathrm{a}$ voluntária M. H. dispensaram a ele. Segundo ele, as duas desempenharam um papel que até então ele não conhecia, elas confiaram nele, mesmo diante de algumas recaídas.

Está terminando o terceiro ano do ensino médio e trabalha como office boy. Deseja cursar Relações Internacionais ou Ciências Sociais. Teve poucas notícias de sua mãe; nunca foi procurá-la ou foi procurado por ela.

Com quase dezenove anos, ele não pode mais permanecer na AMC, que abriga jovens até a idade limite de dezoito anos. Embora concordando com a norma, que o obriga a procurar outro lugar, ele parece resistir a essa mudança.

A análise do seu HTP sugere: forte tensão interna; humor deprimido; carência afetiva; sentimentos de vazio interior; supervalorização do intelecto; fraca identificação com a figura masculina; repressão de seus interesses sexuais genitais; idealização das relações e razoáveis recursos do ego.

A análise das estórias do TAT indica: razoáveis recursos de ego; busca de identidade; dificuldades no relacionamento interpessoal; persistente receio de abandono ou luto; confiança na superação de dificuldades e na adaptação à vida.

Pm. apresenta alguma instabilidade na manutenção da sua linha de conduta, revelando uma estruturação de ego comprometida, possivelmente, devido a intensos impulsos destrutivos mantidos sob forte controle com o auxílio da intelectualização. Em tese, esse sujeito que se desenvolveu razoavelmente bem, parece necessitar de um ambiente ou de uma pessoa que lhe forneça a segurança e a continência afetiva, necessárias na elaboração de seus impulsos agressivos, para que ele possa não sucumbir facilmente às frustrações e às dificuldades naturais da vida, podendo, assim, utilizar melhor sua energia para a maturação da personalidade.

Durante as entrevistas Pm. mostrou-se cooperativo, porém com um humor bastante lábil, havendo ocasiões em que ele se recusava a conversar e se mantinha isolado. Em alguns dias ele não voltava para o abrigo e não contava para ninguém onde havia passado a noite. Pm. demonstrava desconfiança e necessidade de aprovação e, tinha dificuldades em estabelecer relações. Desenvolveu bastante seu lado intelectual, aspecto que estimulou o desenvolvimento de sua auto-estima positiva. Demonstrou ter consciência que o estilo vida gera conseqüências e manifestou grande vontade de mudar.

Mantivemos contato com os profissionais da AMC em meados do segundo semestre de 2004 e soubemos que Pm., não podendo mais continuar no abrigo, voltou para as ruas, embora tivesse mobília, roupas, emprego e apoio de pessoas da casa. Ele foi visto por alguns funcionários, sujo, mal-vestido e afirmando ter voltado a morar nas ruas.

Uma das outras pessoas observadas para este estudo foi Cf., uma garota de quinze anos. . Ela tem onze irmãos, com uma diferença média de dois anos entre eles. Morava com sua família, em um sítio, onde seus pais eram caseiros, na região rural de São Paulo. Seu pai mantinha uma plantação de maconha, para uso pessoal, dentro da propriedade e, quando descoberto, foi demitido, forçando a vinda de todos os membros da família para São Paulo, morar nas ruas. Na época Cf. tinha quatro anos de idade.

Ocorreram, então, importantes mudanças na vida de Cf. O grupo familiar perdeu o vínculo com o local de origem: com seus referenciais culturais; relações sociais; modo de vida e de subsistência, tendo pela frente o desconhecido, a insegurança quanto ao futuro. A mudança para a metrópole expôs a família (pai, mãe grávida e oito filhos) à falta de moradia, de meios próprios de subsistência, de referências socioculturais e de dignidade.

Quando Cf. tinha, por volta de cinco anos de idade seu pai foi demitido do trabalho, a partir daí ele começou a beber e a usar drogas pesadas. As brigas familiares tornam-se freqüentes e culminaram na separação dos pais.

A mãe de Cf. logo encontrou um novo parceiro, U., que passou, então, ser o padrasto de Cf. e de seus irmãos. Quando Cf. tinha cerca de sete anos, nasceu A, filha de sua mãe com seu novo companheiro. U. também era alcoólatra e muito violento, chegou a bater na companheira, e em seus enteados e filhos; chegou a jogar óleo fervente no rosto de sua mulher, mãe de Cf. Por isso, foi denunciado e preso, entretanto, ficou detido por apenas uma semana, voltando em seguida com ameaças. Na ocasião, Cf. e um de seus irmãos bateram com um tijolo e pedaços de madeira em U., que depois disso foi embora.

Cf. contou que sua mãe, que era "forte e trabalha- 
dora”, tornou-se alcoólatra, desenvolveu uma anemia persistente e deixou de se tratar de epilepsia, passando, assim, a ter problemas na manutenção do seu trabalho. Com isso, a família passou a ter dificuldades financeiras. Aos dez anos, Cf., e alguns de seus irmãos passaram a ficar mais tempo nas ruas. Nessa época, seu irmão E, com doze anos, foi preso por roubo.

Também nessa época nasceu L, seu meio-irmão. Cf., que estava com doze anos, e morava na Praça da Sé, começou a usar drogas e passou, em pouco tempo, das drogas leves para os solventes e o crack.

Quando Cf. tinha treze anos, seu pai foi assassinado por causa de dívida com o chefe do tráfico. Essa perda foi muito significativa, pois Cf. disse sentir saudades do pai e lembrou com carinho de suas brincadeiras e estórias. Nessa época, ela passou a morar com seus dois irmãos na AMC, onde foi entrevistada.

Cf. disse que visitava sua mãe quinzenalmente e, se as condições da casa fossem outras, ela iria morar com ela. Em outro momento, Cf. afirmou que ficava uma semana na casa da mãe, e quando se cansava, ia para a AMC e vice-versa.

Disse ter bom relacionamento com suas irmãs $\mathrm{P}$ e J, afirmou que elas são compreensivas, diferentemente dos outros irmãos. Contou que briga muito com sua irmã E.

Afirmou condenar atitudes como: abandonar os pais na velhice, ou matá-los por causa de dinheiro, lembrando de um caso recente, bastante divulgado pela mídia.

Cf. disse não ter tido boas experiências com as drogas, pois era constantemente incomodada pela polícia e: "por causa da droga, minha mãe não conseguia encontrar a gente".

Ela contou que, além da educação, a melhor coisa que sua mãe lhe deixou foi "saber respeitar os outros". Ela fez curso de culinária no Projeto Quixote e considerou esse curso a coisa mais importante de sua vida, mas não o concluiu por falta de dinheiro para a condução. Demonstrou interesse em voltar a estudar e disse que gostaria de ser professora de Educação Física ou de Matemática. Lembra que gostava de estudar e que teve boas experiências com suas professoras. Todos os seus irmãos estudaram, mas alguns iam para a escola apenas por causa da merenda e, depois de comer, voltavam para a rua; no fim das aulas, pegavam o caderno de alguém e copiavam a lição.
Cf. tem namorado e vida sexual ativa. Entre onze e doze anos tinha muitos pesadelos, e um deles sempre se repetia: "eu era jogada do alto de um prédio" . Nessa época, seu padrasto ainda morava com a família e fazia constante ameaças a todos. Quando sua mãe se separou dele, Cf. e todos foram morar em outra casa, seu sono voltou ao normal.

Eles moraram um tempo na casa de sua avó materna, de quem Cf. não gosta muito, pois sempre que sumia, a avó achava que havia sido ela: "Sempre que algo some na casa, ela pensa que fui eu, só porque nós moramos na rua”.

Cf. considera-se uma pessoa calma e afirma que o que a deixa nervosa "são as pessoas que falam sobre ela sem saber direito como são as coisas" .

Na AMC, informaram-nos que as fugas de Cf. para as ruas são muito freqüentes, quase semanais, e, nessas ocasiões, ela consome muita droga. Sua família vive em condições de miséria.

O resultado do teste HTP indica que Cf. tem razoáveis recursos de ego, mantendo certa coesão interna; possui predominância de pensamento mais concreto, com pouca capacidade de abstração; tendências a reagir de forma impulsiva; dificuldades em estabelecer um modelo como referencial. Foi possível notar sentimentos de insegurança e inferioridade; uso freqüente de mecanismos de idealização; conflito edipiano aparente em alguns desenhos.

No teste TAT encontramos: intensa atividade de fantasias destrutivas e de retaliação; presença de tendências edipianas e sentimentos de culpa; ela parece sentir-se doente e necessitar de cuidados; usa da idealização como defesa; percebe a presença de bons objetos internos que podem auxiliá-la na vida; demonstra desejos de reparação.

Cf. foi cooperativa nas entrevistas, entretanto, nos deu a impressão de descaso com o entrevistador, demonstrado em seus atrasos e em sua atitude durante as conversas. Não manifestou desejo de buscar autonomia e independência, mostrando certa acomodação na condição de abrigada. Demonstrou-se uma jovem pueril, desorientada e bastante desconfiada.

Outro entrevistado foi Fm., de dezessete anos, que morou com os pais e o irmão na cidade de Santos (SP), onde também moravam seus bisavós. Seu pai bebia e batia na mulher e nos filhos. Quando Fm. tinha aproximadamente dois anos de idade, sua família veio para 
São Paulo; ficaram morando nas ruas até que seus pais se separaram. Fm., sua mãe e seu irmão, foram morar com os avós maternos, que são imigrantes russos. Desde então, Fm. não vê o pai. Quando Fm. tinha seis anos, nasceu Y, filha de seus pais, que se encontravam eventualmente.

Fm. demonstrou sentir falta do carinho da mãe; disse que sua avó lhe dá um pouco de carinho e que seu avô, que faleceu há dois anos, de câncer, lhe dava muito carinho: "Ele era um pai para mim". Seu avô lhe deixou o exemplo de honestidade, e sua avó lhe ensinou a nunca maltratar ninguém.

Fm. contou que sua mãe é muito brava e nervosa e que gostaria muito de não depender nem dela nem de sua avó. Disse que sua família é bastante religiosa. Ele e seu irmão brigam constantemente.

Já saiu várias vezes de casa, indo para a Praça da Sé e para abrigos alegando brigas em casa. Na última fuga, educadores do Projeto Travessia o encaminharam da Praça da Sé para a AMC, abrigo que ele já conhecia.

Contou que já experimentou maconha, mas não gostou, e que não faz uso de drogas.

Fez um grande amigo, N, quando se mudou para Francisco Morato (bairro de São Paulo), tem boas lembranças do companheiro e diz que nunca brigaram. Declarou-se "esquentado", briga por qualquer coisa, mas nunca brigou com N. Disse que ele é calmo, “cabeça feita”, trabalha, estuda, não usa drogas, vai à Igreja e sempre aconselha Fm. a não fugir de casa. Disse que N. quer ser médico. Fm. disse que gostaria de ser jogador de futebol e, se não der, quer tentar ser médico ou enfermeiro "pra ajudar as pessoas".

Em dois empregos anteriores, arranjados pelo serviço social da AMC, foi acusado de roubar dinheiro. Confidenciou que rouba coisas pequenas, mas que não gosta de roubar. Já foi convidado várias vezes para roubar no farol com outros garotos e não aceitou. A assistente social contou que ele tem o hábito de pegar coisas dos garotos do abrigo.

Fm. disse estar apaixonado por uma garota, $\mathrm{P}$, de quem se desencontrou há três meses. Contou que a melhor coisa nela é o beijo. Pergunta sempre por ela para os meninos que chegam e disse ter certeza de que ela gosta dele também. Disse ter, atualmente, um "caso" com uma menina, mas que ela ainda está indecisa. Quando Fm. está namorando se sente o "homem mais feliz do mundo”. Disse não gostar da solidão.
A análise dos desenhos de Fm. indica: estado emocional deprimido; utilização predominante do pensamento concreto, pouca capacidade de abstração e simbolização; uso intenso da idealização e da cisão como defesas; nota-se ainda um sentimento de vazio interno; a necessidade de contato pessoal, porém, de forma vazia, destituída de afeto; sentimentos de nãoaceitação do meio, atitudes de oposição; também que ele possui razoáveis recursos egóicos.

A interpretação das estórias do TAT sugere: fortes sentimentos de agressividade e tendências à impulsividade; intensos sentimentos de culpa, comportamentos de autopunição, além de um estado de humor depressivo; ele justifica sua própria agressividade como resposta às agressões que partiram inicialmente do meio externo; tem dificuldade em simbolizar e; espera que as coisas se resolvam sozinhas; apresenta tendências à idealização.

Fm. é um rapaz de poucas palavras, e demonstrou ser revoltado com sua família. Aparentou um jeito de "bebê chorão" por meio de sua fisionomia e de suas lamentações.

O outro entrevistado, Em. nasceu em Garanhuns (PE) e veio com sua mãe e irmãos para São Paulo quando ele tinha quatro anos de idade, por causa da separação de seus pais. Seu pai era alcoólatra.

Sobre o convívio familiar, queixou-se: "a gente não convive como irmãos". E não sabe ao certo as datas de aniversário dos familiares, porque eles nunca comemoraram esse dia: "aniversário é só mais um dia" Disse que nunca se deu bem com sua irmã mais velha e, ao se referir aos irmãos, comenta: "a gente só se misturou depois de grande”. Um grande desejo de Em. é ter seu aniversário festejado.

$\mathrm{Na}$ época da entrevista sua mãe morava com um companheiro; ela tinha oito filhos. Em. não se recorda do nome deste companheiro. A mãe passava o dia trabalhando fora e seu tio e vizinho, que era o chefe do tráfico de drogas, pedia que ele levasse entorpecentes de uma favela para outra, desde os sete anos de idade. Aos oito anos, Em. saiu de casa e, como conhecia a região do Brás, juntou-se a um grupo de garotos que viviam pelas ruas desse bairro. Afirmou que nessa idade já fumava cigarro e maconha e suas companhias eram adolescentes, garotos bem mais velhos que ele e adultos que trabalhavam no tráfico. Por volta dos nove anos, Em. foi encaminhado pela polícia ao SOS 
Criança, que o levou de volta para casa, apesar da sua resistência. Dois meses depois, já havia se reaproximado do tio traficante e voltou a trabalhar para ele. Voltou a estudar e completou a segunda série do ensino fundamental, a terceira ele repetiu várias vezes e não terminou. Segundo Em.: "por motivos de trabalhar com a droga, aí pra mim o ritmo da droga virou uma rotina”. Disse que aos nove anos já usava crack, mas não queria que ninguém soubesse. Aos onze anos, voltou para o Brás onde se juntou a uma nova turma, substituiu o crack por cola, Thiner e lança-perfume: "eu gostava da brisa, da loucura que passava, um modo criativo assim entre aspas, um jeito diferente, gostei” . Foi novamente encaminhado para o SOS Criança, de onde fugiu para a Praça da Sé. Começou a roubar e a pedir dinheiro. Passou a freqüentar o Pátio do Colégio; ficava a maior parte do tempo usando drogas. Conheceu N, uma jovem traficante, por quem se afeiçoou. Ele trabalhou para ela, vendendo drogas. Nessa época, foi pego roubando e os policiais o encaminharam de volta para sua casa, onde ele ficou por quase um ano. Voltou a trabalhar para seu tio, parou de usar "pedra" e passou a usar cocaína e álcool. Ganhava seu dinheiro e comprava suas roupas: "isso sem minha mãe saber, até tinha as desconfianças dela” Contou que, por ser sobrinho do chefe do tráfico, recebeu a incumbência de cobrar as dívidas do seu tio. Ganhou, então, um revólver calibre trinta e oito, aos doze anos de idade. Passou a intimidar os devedores e a ser temido pela vizinhança, até "pelo diretor da escola". A condição de poder lhe trazia, entre outras vantagens, o interesse das meninas. Com treze anos, voltou para o Brás, para a mesma turma da primeira fuga. Com essa turma passava os dias nas estações de trem das proximidades, roubando e divertindo-se. Certa vez, em cima do trem, percebeu a segurança esperando por ele na próxima estação, pulou em um telhado. 0 telhado quebrou e ele caiu perdendo os sentidos. Acordou de um coma duas semanas depois, com um pedaço de platina no crânio.

Em. voltou para a Praça da Sé. Foi preso novamente e encaminhado para a Unidade de Atendimento Inicial (UAI), unidade da Febem, onde ficou um mês, em seguida, foi re-encaminhado para o SOS Criança, e daí voltou para as ruas. Contou que houve uma nova prisão que gerou um processo. Ele deveria cumprir a pena em regime de semiliberdade na Unidade Educacional
(UE). Lá encontrou “todo mundo que é do crime”. Nesse local, o jovem sai durante o dia para estudar ou trabalhar, devendo retornar à noite. A instituição providencia, em alguns casos, trabalho ou estudo. Depois de quatro dias, Em. saiu com alguns amigos, foi parar em uma favela próxima e foi logo apresentado ao dono do tráfico, que conhecia seu tio e vários de seus amigos. Ele passou imediatamente a trabalhar no tráfico e não voltou para a UE. Passadas algumas semanas, Em. foi para a casa de uma tia, onde ficou escondido, pois havia entrado em situação de "busca e apreensão”, por ordem do Juizado de Menores. Fez amizade com a vizinhança e logo começou a participar do grupo de usuários. Contou que sua tia começou a ficar desconfiada de seu vício e que a essa altura sua mãe já devia saber: "aí fiquei assim, comecei a ser discriminado já pela minha família toda, que não curtia o negócio, (...) eu tava sem chance (...) pra eu poder me regenerar e tal, então me afundei mesmo" .

Manteve um relacionamento com uma garota e os dois tiveram uma filha. E. morou na casa da namorada por aproximadamente um ano. A avó da moça tomou a guarda da filha deles, pois sua neta estava envolvida com drogas. E diz que voltou para a casa de sua tia e, depois disso, ele nunca mais viu a filha nem a mãe da menina.

Muito envolvido com as drogas, sentindo sua saúde prejudicada e perseguido pela polícia, E pediu à sua tia para ser internado em uma clínica para drogadictos.

Contou que lutou contra a vontade de usar droga enquanto estava na clínica e conseguiu certo controle sobre si mesmo Afirmou que consegue se controlar até hoje, quando já está em liberdade, entretanto, algumas vezes, "dá uma escapadinha”, mas esforça-se muito para não recair. Depois de ter saído da clínica, o juiz decretou condição de Liberdade Assistida e ele passou a ser acompanhado por uma assistente social. Afirmou que está há quase três anos sem usar "nada".

Em outro momento, Em. revelou que o que o levou para a casa de recuperação foi "mais a questão que eu estava sentindo falta da família, eu tava percebendo que eu tava me afastando da minha família” . Mesmo tendo oito irmãos, não tinha convívio familiar, pois ele passava a maior parte do tempo na rua e, quando vinha para casa, chegava drogado e não se relacionava com ninguém. 
Contou que, quando ficava triste, com saudades de sua mãe, procurava se drogar ou então roubava dinheiro e ia com uma prostituta para um hotel da região da Rua Guaianazes, ou então ficava sentado em um "mocó", embaixo das escadas da Praça da Sé. "O que me fazia falta era minha mãe do meu lado, minha mãe sempre esteve do meu lado, mas não do meu lado totalmente, porque ela nunca chegou pra conversar comigo, pra saber o que tava acontecendo, pra saber por que eu tô triste, a minha mãe..., o trabalho dela..., era só isso trabalhar, colocar as coisas dentro de casa e o resto vocês que se virem, entendeu?" .

Em. disse que hoje aconselha sua mãe a controlar melhor seus irmãos menores, para que eles não tenham o mesmo destino que ele.

Afirmou que, quando sentia saudades e voltava para casa, sua mãe sempre o aceitava de volta, mas depois "não olhava na (...) cara" .

Não se lembra de seu pai na infância. Com quinze anos de idade, Em. foi mandado para a casa do pai, em Garanhuns, na tentativa de afastá-lo das drogas. Viajou com a idéia de matar seu pai, pois sentia muito ódio dele. Quando chegou à cidade, demorou três semanas para falar com o pai e, com o,tempo, seu ódio foi arrefecendo. Na cidade, trabalhou em uma oficina mecânica e depois em um desmanche de carros. Namorou algumas meninas, incluindo sua prima, com quem manteve um relacionamento escondido. Conheceu os usuários de crack e de cocaína da região e passou a andar com eles. Seu tio percebendo o que estava acontecendo, mandou-o de volta para São Paulo.

Um fato marcante na vida de Em. foi um relacionamento que manteve com uma menina que era evangélica e de uma classe social mais elevada. Essa moça "desafiava os pais [...] para ficar comigo". Ela sempre o chamava para ir à Igreja;. Em. afirmou que ela queria livrá-lo das drogas.

Contou que é o único entre seus irmãos que viveu em situação de risco; os outros moram com sua mãe e, uma de suas irmãs está casada.

Ele disse ressentir-se da vida que levou, e afirmou que a companhia de sua mãe lhe fez muita falta. Queixou-se da ausência de alguém que tivesse cuidado dele, orientando-o "para o bem". Afirmou que seu melhor amigo é uma pessoa que estuda, trabalha e freqüenta a igreja.

Ele aparentou ser um jovem comunicativo, e que mantém bom contato social com os funcionários do
Abrigo, assim como com os meninos que lá freqüentam. Aprendeu a técnica de panificação e auxilia um funcionário que dá aulas a jovens interessados, ganhando, por isso, uma bolsa auxílio do Centro de Defesa dos Direitos da Criança e do Adolescente (CEDECA), uma parceria entre o Centro de Convivência Nossa Senhora do Bom Parto (onde foi entrevistado) e, o Governo do Estado.

Os desenhos do HTP indicam: fortes tendências de cisão do ego (um "eu" pensa e "outro" age impulsivamente); desejos de estabelecer contato com o mundo externo e de obter apoio de pessoas que possam ajudálo; intensa necessidade de aceitação; fantasias de esvaziamento interior de recursos pessoais, auto-estima e controle dos impulsos; tendências à procura de satisfações dentro da modalidade oral, isto é, de forma imediata e voraz; sentir a influência do passado vivida como feridas; e possuir razoável estrutura interna.

As análises das estórias do TAT apontam para: sentimento de incapacidade de enfrentar, predominantemente, o processo secundário do pensamento; forte necessidade de apoio de outras pessoas; tendência a responsabilizar os outros por sua história de vida; lamentação de não ter tido recursos pessoais para ter evitado a vida que levou; tendência a utilizar as formas mais primitivas de satisfação, como imediatismo, voracidade, inveja e impulsos agressivos; desejos de assumir responsabilidades e comportamentos socialmente valorizados.

Observou-se em Em. uma extroversão levemente exagerada, dando a impressão de um estado de ansiedade permanente. Seu discurso é exaltado e ininterrupto, deixando pouco espaço para a interlocução.

Outro sujeito entrevistado foi Pf., de tem dezesseis anos e um irmão de dezoito. Seu pai foi assassinado quando ela tinha três anos de idade. Ela contou que se lembra das repetidas vezes que seu pai dizia: "Olhem, meus filhos, se um dia eu morrer eu quero que vocês...”, e da apreensão de sua mãe, que chorava com freqüência.

Mais tarde Pf. soube que ele estava ameaçado de morte por causa de dívidas. Após a morte de seu pai, sua mãe pediu para dona $\mathrm{D}$, para quem trabalhava, que cuidasse da menina. Assim, Pf. morou com dona D, até seus dez anos de idade, quando sua mãe pediu em juízo para ter novamente a sua guarda.

Pf. tinha bom relacionamento com dona $\mathrm{D}$, a quem chamava de "vó". Também gostava do filho de dona D, 
que se tornou seu padrinho. Contou que fez muitos amigos na sua infância.

Seu irmão R, é usuário de drogas, não trabalha e mora com sua avó desde os cinco dias de vida.

Pf. está na AMC há três meses, veio encaminhada pelo Projeto Criança Cidadã. Estava na Praça Marechal há aproximadamente um ano e meio. Pf. e os amigos passavam a maior parte do dia cheirando cola, só comiam quando pediam, ou às sextas-feiras, quando alguns voluntários iam levar comida, à noite, para os moradores de rua. Contou que, havia dias, que não conseguia dormir de "tanta fome". Desenvolveu uma anemia grave e foi encaminhada para um hospital onde tomou soro por dois dias.

Durante os dez meses que Pf. passou na praça, sua turma era a mesma, cinco meninas e quatro meninos. Com o tempo, alguns foram se afastando, ficando apenas Pf. e outros três jovens. Ela contou que dois rapazes, um de vinte e outro de vinte e três anos, apareciam por lá depois do trabalho e protegiam as meninas. Eles estavam em liberdade condicional, prestando serviço comunitário. Algumas vezes traziam alimentos e roupas; outras, dormiam no local para protegê-las.

Pf. relatou que parte dos efeitos do uso da cola é muito desagradável: uma sensação de sufocamento, tontura e, muitas vezes, grande rebaixamento da consciência, com perda de memória. Perguntada sobre o porquê de aspirar cola, ela respondeu: "Porque tinha muitas vezes que eu ficava sentida, por que eu não queria me desentender com minha mãe e, para esquecer tudo isso, eu ficava cheirando cola".

Certa noite Pf. foi a um posto policial, e pediu que a encaminhassem para algum lugar, pois não queria mais ficar na rua. Foi encaminhada para o Projeto Taiquara, onde brigou com uma menina e a machucou. Com medo de ser encaminhada para a Febem, fugiu e foi para a Praça da Sé, onde encontrou G, com quem foi Praça Marechal, se juntar a uns amigos de G. Alegou que fugiu de casa, por desentendimentos com a namorada de sua mãe. Contou que sua mãe, logo após a morte de seu marido, juntou-se a mulher chamada K, que era policial. Quando Pf. voltou a morar com a mãe, aos dez anos de idade, o relacionamento entre as três era bom. Aos treze anos, as relações dentro de casa tornaram-se tensas, pois, segundo ela, $\mathrm{K}$ passou a ser exigente e rigorosa. Cobrava dedicação aos estudos e ajuda na casa, sem direito à diversão. Pf queixou-se que sua mãe não a defendia, sempre dando razão à K. Certa vez, Pf. desobedeceu K, e esse fato gerou uma briga com sua mãe, provocando sua primeira fuga. Ela foi para Santos (SP) de carona. Quando chegou, ficou com medo e telefonou pedindo para que a mãe fosse buscá-la. A partir daí as fugas tornaram-se constantes.

Pf. contou que, em dos aniversários de sua mãe, K trouxe presentes e três CDs de música e trancou-se no quanto com sua mãe. Pf, que queria sair para brincar, olhou pelo buraco da fechadura e viu as duas se beijando, o que lhe provocou nojo. Em outra ocasião, Pf. viu uma amiga de sua mãe acariciando-a. Pf. xingou a mulher e contou o acontecimento à K. Sua mãe negou o ocorrido.

Quando Pf. fez quinze anos, sua mãe fez uma festa. No dia seguinte, sem ela entender por que, K lhe bateu. Pf saiu de casa e passou a buscar apoio na casa de amigos e parentes, que não a acolheram. Telefonou para sua mãe e ouviu dela que já havia escolhido a rua, que não voltasse. A mãe de Pf. separou-se de K. Pf. conta que sua mãe mudou completamente depois disso, tornou-se mais carinhosa: "ela não pensa só nela e na mulher, ela tá namorando com um cara agora, mas ela pensa primeiro nos filhos dela, para depois pensar no cara”.

Pf. contou que J. [sua mãe], que estava trabalhando em uma lanchonete, tem intenção de alugar uma casa e levar seus filhos para morar com ela. R, seu irmão, avisou que não iria, continuaria morando com a avó. Na época da entrevista, J. estava morando na pensão com a mãe, avó de Pf, e seu filho R. Pf. afirmou que o lugar é muito pequeno para acomodá-la também. Pf. revelou: "eu sempre quis morar com minha mãe, depois, se não fosse por essa mulher, eu não tinha nem fugido de casa, não sabia nem o que era a rua”. Certa vez, seu irmão foi morar com elas, mas K. tratou-o mal, e ele voltou para a casa da avó. Pf. afirmou que K. tinha muito ciúme dela com a mãe.

Ela estava cursando a oitava série.

Declarou que namora homens e não sente atração por meninas. Seu primeiro namorado era traficante de drogas e batia muito nela. Engravidou desse rapaz quando tinha catorze anos de idade; ele tinha dezoito. Na ocasião, a mãe de Pf. falou que era para ela escolher entre morar com o namorado e morar na rua. Sua mãe queria que ela abortasse, mas ela queria ter 
o filho. J. pediu para um "macumbeiro" fazer um trabalho. Insistiram para que ela tomasse um chá, feito com "maconha", que ela recusou: "nisso, eu não sei o que aconteceu, de um dia pro outro, eu me revoltei e falei que não queria o filho". Sabendo que ela tinha mudado de opinião, o "macumbeiro" foi à sua casa. Deu-lhe um chá que a fez vomitar e socos na barriga, entretanto, nada aconteceu. Pf. saiu à procura de seu namorado. Quando o encontrou, contou-lhe tudo. Ele respondeu que assumiria o filho, e, que ela passaria a morar na casa dele. Quando sua mãe foi procurá-la, Pf. fugiu, e encontrou com a irmã de seu namorado na rua. Como Pf. tinha ordens de não sair de casa, sua cunhada lhe bateu com um pedaço de madeira, um dos golpes foi na barriga, provocando o aborto.

Pf. contou que era muito apegada a seu pai. Ele era borracheiro. Revelou que ele a defendia. Quando sua mãe saía, aos sábados à noite, para ir dançar, deixando os filhos sozinhos, o pai saía para buscá-la, batendo nela quando chegavam em casa. Disse que ele a colocava no colo e falava: "Filha, eu sei que tudo o que você viu agora, quando for mais tarde, quando você for mais velha, você vai lembrar, mas o que o pai fez com a mãe agora, foi porque ela deixou vocês chorando. Se um dia o pai morrer, quando você estiver sofrendo, eu sempre vou estar do seu lado, sempre vou aliviar um pouco o seu coração, pra você parar de sofrer" "Sempre quando eu choro, assim, eu lembro das coisas que ele falou, e ou eu pego no sono, ou, eu paro de chorar" . Em outro momento, falando novamente sobre o relacionamento dos pais, Pf. disse: "Eles raramente brigavam, era raro eles brigarem, então, meu pai não podia ver eu chorando, que ele vinha e ficava me agradando. Os dois raramente brigavam, ficavam num clima bom, assim, sabe, minha mãe cuidando de mim e de meu irmão, ele [o pai] ia trabalhar, voltava e ajudava minha mãe cuidar de nós”. Pf. disse que não tinha lembranças de sua mãe durante a infância. Sua mãe contou que ela é muito parecida com o pai, decidida e encrenqueira e sentimental, Pf. contou que se apega com muita facilidade às pessoas. "Meu pai era assim, ele gostava de ajudar bastante gente e eu, por mais que eu não tinha nada, deixava de comer pra dar para os outros". Pf. descreveu sua mãe como uma pessoa arrogante, fechada e que, embora seja carinhosa, não demonstra: "a minha mãe quer chegar em nós, quer fazer um carinho, só que ela tem medo de fazer e, depois a gente pegar e dar mancada com ela". Disse que ela e sua mãe conversavam muito sobre namorado, sexo, doença, e prevenção. Contou que as duas saíam para os bailes e ficavam dançando: "parecia que a gente sempre teve aquele amor uma pela outra, só que era só na festa, chegava em casa a coisa mudava, parecia que ela só queria mostrar que estava feliz, assim, perto da gente, porque as amigas dela estavam ali”. Pf. contou que sua mãe mudava muito de humor. Ficava triste por dias, fechada, chorando e não falava nada sobre o assunto. Nos dias que estava feliz, as duas saíam e conversavam muito. Relatou que sua mãe sempre a ajudou nos estudos. O desejo de Pf. é formarse em pediatria.

Referiu que nunca teve doença importante, mas seu irmão sempre apresenta crises de falta de ar, chegando a ser hospitalizado: "de tanto fumar maconha", interpretou Pf. Seu irmão está em Liberdade Assistida. Ela contou que não está usando drogas no momento.

Pf. revelou o nome dos educadores e abrigados da AMC, com quem ela se dá bem. Segundo ela, a AMC é diferente de outros abrigos, nos quais a disciplina era muito rígida, proibindo-se o cigarro, saídas, e obrigando os jovens a usarem a "roupa da casa". Manifestou que se sente acolhida na AMC.

A análise dos desenhos sugere: fraca discriminação entre realidade interna e externa; tendência a fantasiar para defender-se do contato com a realidade; dificuldades para definir sua identidade sexual; introjeção de bons objetos.

A análise do TAT indica: sentimentos depressivos; opressão; sentimentos de perseguição pelo ambiente externo; sentimentos de incompreensão; recursos internos para enfrentar as exigências da vida.

Durante as entrevistas, Pf. demonstrou comportamento pueril, e traços de sedução para controlar as pessoas.

Algum tempo após nosso contato inicial, soubemos que ela havia engravidado e, estava morando com sua mãe.

\section{Interpretação dos Dados}

Constatamos que as famílias de nossos sujeitos passaram por várias circunstâncias potencialmente adversas para a estabilidade emocional de seus integrantes, assim como, para a qualidade de suas relações interpessoais. Esses fatos ocorreram em épocas pre- 
coces do desenvolvimento dos jovens entrevistados. Algumas dessas famílias viveram nas ruas, com histórias de desemprego, migrações, alcoolismo e uso de entorpecentes, desentendimentos conjugais, agressões físicas, separações e mortes. Foi em ambientes assim que nossos entrevistados nasceram e passaram seus primeiros anos de vida. Ambientes propícios a estresse, negligência, rejeições (declaradas ou subliminares), violências e rupturas. Circunstâncias que provavelmente tiveram influência na estruturação de suas personalidades.

Os jovens entrevistados viveram nas ruas desde a idade muito precoce. A maioria abandonou os estudos, alguns praticaram delitos, como roubos, tráfico e uso de entorpecentes e todos apresentaram desenvolvimento psicológico comprometido.

Os testes de personalidade apontaram, de maneira geral, a utilização intensa de mecanismos de defesa arcaicos como cisão $0^{10}$, negação $0^{11}$ e idealização ${ }^{12}$. 0 uso intenso desses mecanismos, implica em dificuldades para o desenvolvimento emocional.

Podemos apontar para fortes sentimentos de rejeição, exemplificados quando entendem alguma crítica de forma absoluta, como se referisse a todo o seu ser. Isso resulta em sentimento do tipo "ninguém gosta de mim".

Alguns deles foram bem longe em suas trajetórias, quase atravessando a fronteira para um território difícil de voltar. Alguns de nossos sujeitos reconsideraram seu estilo de vida, à medida que iam sofrendo e sendo testemunhas dos danos causados por essa for- ma de vida, ou seja: o uso de entorpecentes cada vez mais freqüentes e em maior dosagem; eles próprios e seus amigos sendo presos, envolvidos em brigas ou mortos; perseguidos pela polícia. Isso nos leva à hipótese de fortes impulsos autodestrutivos, entretanto, alguns de nossos entrevistados declararam que nas ruas também encontram amizade, solidariedade, proteção, afeto e organização, declarações que coincidem com os achados de Mejía-Soto (1998).

Entre os jovens entrevistados apenas dois, Pm. e Fm., conseguiram adiantar-se em seus estudos e manter um afastamento das drogas por períodos mais longos que seus companheiros.

As duas meninas tinham recaídas quase semanais, passando semanas nas ruas drogando-se, com crises de arrependimento que se seguiam. Diante disso, podemos pensar que houve um fracasso na elaboração ${ }^{13}$ das fantasias infantis de onipotência. Essa elaboração poderia levá-las, gradativamente, a submeteremse aos limites da realidade. Essa dificuldade de elaboração conduziu-as a uma jornada que só vai ser considerada depois de sofrerem na carne as conseqüências de sua recusa em aceitar os próprios limites. A essa altura, já colecionavam em suas histórias: dependência de drogas pesadas; convívio com a violência; saúde abalada; falta de perspectivas; discriminação social e familiar. A realidade fez sentir seu peso.

De acordo com Kalina (1980), a ingestão de drogas dá ao usuário a ilusão de superação de conflitos e da depressão. Terminado o efeito, os conflitos e a depressão voltam a se manifestar, renovando o anseio

10 "Por ele, os recém-nascidos, em virtude de um 'ego incipiente', separam em duas partes o objeto primário parcial que é o seio da mãe. Uma parte seria aquela que lhe é gratificante - a parte boa, o seio bom - e a outra seria aquela 'responsável' pelas frustrações da criança - a parte má, o seio mau”. A cisão transformaria o instinto de morte em duas porções. Uma projetiva, pela qual o ego joga para fora dele e para dentro do objeto relacional (que lhe é externo) parte de si, que contém o instinto de morte. Daí o seio, que é esse objeto parcial, passa a ser sentido como ameaçador, perseguidor e mau para o ego. A outra porção continua pertencendo ao ego e transforma-se em força agressiva para rebater os perseguidores. Também o instinto de vida, por meio da libido, é cindido em duas partes. Uma que projeta sobre o objeto original da relação (o seio e suas extensões) um esforço instintivo para a preservação da vida. Outra parte que continua pertencendo ao ego é utilizada para construir relações libidinais amorosas e prazerosas com o objeto relacional. (Almeida, W. C., 1996, p. 55)

11 No caso desse mecanismo de defesa originário da repressão, as imagens teriam acesso à consciência parcialmente, mas, mesmo assim, para terem a oportunidade de serem negadas. A dinâmica é mais ou menos assim: o fator repressivo seria, temporariamente, removido e o reprimido afloraria por um átimo de tempo, dando chance à consciência para negá-lo. Segundo Fenichel a capacidade de negar partes desagradáveis da realidade é a contrapartida da realidade alucinatória. (Almeida, W. C., 1996, p. 40)

12 É a defesa que nos faz acreditar na bondade e beleza dos objetos (pessoas, coisas, idéias). (...) Ninguém e nada terão defeitos para o idealizador. No entanto, deve-se ressaltar o lado positivo da idealização, pois é graças a ela que teremos a capacidade de ter um bom e amoroso relacionamento com o objeto. (Almeida, W. C., p. 68)

13 Elaboração é a capacidade de reviver criticamente as vivências até que elas percam o efeito psicogênico e o potencial patogênico. (Almeida, W. C., 1996, p. 67) 
de utilizar drogas. Estabelece-se, então, um ciclo que desvaloriza o ego e corrói a auto-estima. 0 drogadicto tem grande dificuldade de pensar; ele substitui a reflexão pela ação, que surge como uma fuga de sua imagem desvalorizada.

Podemos dizer que alguns de nossos entrevistados funcionam, predominantemente, sob o regime do processo primário ${ }^{14}$ do pensamento, que busca alcançar o prazer de forma imediata e evitar o desprazer. Isso indica uma inibição na passagem para etapas posteriores do desenvolvimento psicossexual, que possibilitaria a utilização mais intensa e freqüente do processo secundário ${ }^{14}$, que considera a realidade externa e compreende suas leis de funcionamento. $\mathrm{O}$ uso mais constante do processo secundário poderia levá-los a uma atitude mais ativa na busca de sua autoconstrução e inserção social. Alguns desses jovens declararam seu sentimento de frustração, por terem de se defrontar, freqüentemente, com o conflito entre atender suas exigências de prazer fácil e seu desejo de amadurecer, o que parece consumir muito de sua energia e desviá-los constantemente de seus objetivos. Esse processo está bem claro nas palavras de Em. que disse: "não consigo me imaginar adulto" .

Podemos, por outro lado, notar elementos pertencentes ao processo secundário, no movimento de retomada de seus planos, que implicam rotina, disciplina, estudos e o adiamento de satisfações.

Considerando a tendência ao roubo de Fm., recorremos à interpretação de Winnicott (2002), para quem os furtos dos adolescentes podem ser compreendidos como reação à perda de algo bom (afeto, atenção, etc.) que o jovem busca recuperar.

A força dos conteúdos inconscientes pode ser observada no caso de Pm., que embora estruturado em termos materiais, com o apoio de amigos e com planos de vida bem determinados, não conseguiu manter seu projeto de vida. A saída obrigatória do abrigo e o desligamento das pessoas queridas, provavelmente, reatualizou suas angústias, ligadas ao abandono de sua mãe e ele voltou a viver nas ruas.

A não-aceitação da própria agressividade e outros conteúdos considerados negativos, aspectos marcantes principalmente em Fm. e Pf. colocam em ação o mecanismo de projeção, isto é, os conteúdos indesejáveis observados em si são depositados no outro. 0 sujeito passa, então, a gastar muito de sua energia para evitar o contato com partes importantes de seu próprio eu, que são inaceitáveis para ele, dificultando o estabelecimento de qualquer sentimento de responsabilidade pelo próprio destino, o que faz com que ele se sinta vítima das circunstâncias.

Esses jovens também tiveram experiências positivas, que os auxiliaram a manter áreas razoavelmente preservadas em sua personalidade. Alguns encontraram pessoas, em fases mais avançadas de sua infância, que se tornaram elementos de referência positiva em suas vidas. Eles puderam sentir que foram importantes para alguém, fato que parece tê-los auxiliado emocionalmente na constituição de sua segurança interna e sua auto-estima, expressas na busca de integração, no interesse em desenvolver-se e inserirse na sociedade, assim como os desejos de reparar os danos ocorridos. Conforme Klein, os efeitos das condições mais adversas vividas na infância podem ser mitigados por vivências positivas, mesmo em épocas tardias da vida. 0 exemplo mais expressivo é o do jovem Pm. . que parece ter encontrado em sua avó e em algumas pessoas da AMC a continência necessária que lhe forneceu condições de experimentar uma sensação de segurança e confiança.

O que é relevante para o processo de desenvolvimento emocional do ser humano não é a família em si, mas sim pessoas, parentes ou não, com capacidade de investir sua energia, seu interesse, de forma madura e saudável, na promoção do desenvolvimento de alguém.

14 Processo primário e processo secundário são os dois modos de funcionamento do aparelho psíquico, definidos por Freud.

a) Do ponto de vista tópico: o processo primário caracteriza o sistema inconsciente e o processo secundário caracteriza o sistema pré-consciente/consciente.

b) Do ponto de vista econômico-dinâmico: no caso do processo primário, a energia psíquica escoa-se livremente, passando sem barreiras de uma representação para a outra (....); tende a reinvestir plenamente as representações ligadas às vivências de satisfação constitutivas do desejo. No caso do processo secundário, a energia começa por estar 'ligada' antes de se escoar (....); as representações são investidas de uma maneira mais estável, a satisfação é adiada, permitindo assim experiências mentais que põem à prova os diferentes caminhos possíveis de satisfação.

A oposição entre o processo primário e o processo secundário é correlativa da oposição entre o princípio de prazer e princípio de realidade. 
A maioria de nossos sujeitos declarou sentir grande sofrimento interno, por viverem afastados de suas famílias, mas não queriam, ou não podiam, voltar a viver com eles. A fantasia de que as relações familiares ou amorosas representam a felicidade absoluta, observada na maioria dos entrevistados, é a representação da idealização. Essa idealização vem, em geral, acompanhada de ambivalência (sentimentos de amor e forte rejeição que se alternam). A utilização da idealização está em conformidade com os achados de Antoni e Koller (2000, p. 347), que também encontraram em seu grupo, tendência à idealização da família e expectativas sobre a formação de suas próprias famílias, com expectativa de mudança qualitativa nas relações familiares futuras. Segundo esses autores, essa idealização, pode ser vista como proteção diante das situações de risco, as quais os jovens em situação de rua estão expostos.

Alguns irmãos de nossos sujeitos também foram para as ruas; isso só não aconteceu nas famílias de Em. e Fm. Procurando esclarecer essa situação, observamos que os dois irmãos mais velhos de Cf. não viveram nas ruas, estavam casados e trabalhando, na época da entrevista. Isso pode indicar que não sofreram tanto como os menores, por estarem mais amadurecidos na ocasião das difíceis mudanças na vida familiar. Destacamos aqui a especificidade de cada circunstância de nascimento e de desenvolvimento para cada indivíduo. Klein (1971, p. 258) afirma que: "algumas crianças parecem recordar condições externas desfavoráveis sem grande dano para seu caráter e estabilidade mental, ao passo que em outras, apesar de um ambiente favorável, manifestam-se e persistem sérias dificuldades".

O nascimento de irmãos pode, em muitos casos, re-atualizar fantasias inconscientes de abandono e incrementar sentimentos de ciúme, rivalidade e raiva contra a mãe e o irmão. Esses irmãos são vistos como usurpadores do lugar e dos privilégios que a criança desfrutava. Se os cuidados maternos são sentidos pelo sujeito como insuficientes, a existência de um irmãorival pode ser uma ameaça: alguém irá roubar o pouco que lhe é conferido. Neste estudo, as adversidades que alguns enfrentaram na disputa de maternagem, visto o grande número de irmãos, com idades muito próximas, é um fator importante a ser considerado.

Notamos que as duas meninas entrevistadas mantinham uma forte ligação com a figura do pai, o que também aconteceu com Pm. Nesse último caso, temos a figura de um pai idealizado, já que ele o viu apenas duas vezes.

Importante notar que todos os entrevistados cresceram sem a companhia de seus pais (figura masculina). Além da mãe, um pai funciona como lei, civilização, respeito aos princípios e costumes vigentes.

Vale lembrar que indivíduos abandonados tendem a repetir sua história com seus próprios parentes, abandonando-os também.

Esses jovens também esboçam desejos de reparação. Querem constituir sua própria família e reconciliar-se com a família de origem; ajudar os amigos e responsabilizar-se por algo ou alguém. Buscam reconhecimento positivo, melhorar sua auto-estima, e amadurecer. Há, contudo, um desgaste da força vital, na tentativa de neutralizar os impulsos destrutivos e a desagregação $0^{15}$.

Por inferência, baseada na teoria psicanalítica, podemos aceitar a hipótese de que os sujeitos estudados, que tiveram precárias condições de formação de personalidade, ou seja, falta de modelos identificatórios consistentes, constantes, ancorados numa corrente afetiva alimentadora, foram comprometidos no seu desenvolvimento emocional.

Finalizando, afirmamos que estamos de acordo com a hipótese psicanalítica que postula a importante vinculação entre o desenvolvimento emocional de uma criança, e as circunstâncias em que se dá, tanto a gestação como os primeiros anos de vida. Ressaltamos que a dificuldade em proporcionar um ambiente positivo, para o desenvolvimento emocional da criança, pode ocorrer em qualquer nível social, entretanto, as dificuldades socioeconômicas pelas quais passam algumas famílias é um agravante, afetando negativamente a disponibilidade emocional dos pais.

Concluímos esperançosos de ter contribuído no desenvolvimento de uma visão mais abrangente e crítica sobre os fatores que interferem no desenvolvimento humano e no processo de saúde e doença.

15 Caracteriza-se pela cisão da personalidade de forma que uma parte se mantém reprimida e a outra em vigência operativa e plena, com movimento alternado de aparecimento. (Almeida, 1996, p. 36) 


\section{Recomendações}

Defendemos o desenvolvimento de um atendimento que contemple a Saúde Mental, sob a perspectiva de prevenção de doenças de fundo emocional, expostas por este trabalho. Consideramos que intervenções durante o atendimento pré-natal podem ser eficazes.

\section{Referências}

ALMEIDA, W. C. Defesas do ego: leitura didática de seus mecanismos. São Paulo: Ágora, 1996.

ANTONI, C.; KOLLER, S. H. A visão de família entre as adolescentes que sofreram violência intrafamiliar. Estudos de Psicologia, Natal, vol. 5, n. 2, p. 347-381, 2000.

BRENNER, C. Noções básicas de psicanálise. Rio de Janeiro: Imago; São Paulo: EDUSP, 1975.

CALLIGARIS, C. Afeto e família. Folha de São Paulo, São Paulo, 30 dez. 2004. Ilustrada, p. E8. Disponível em: <http://www1.folha.uol.com.br/fsp/ilustrad/ fq3012200414.htm>. Acesso em 30 dez. 2004.

COSTA, J. F. Ordem médica e norma familiar. Rio de Janeiro: Graal, 1979.

FREUD, S. Inibições, sintomas e ansiedade. In: Obras completas. Rio de Janeiro: Imago, 1976. v. 20.
KALINA, E.; KOVADLOFF, S. Drogadicção: indivíduo, família e sociedade. Rio de Janeiro: Francisco Alves, 1980.

KLEIN, M. O sentimento de solidão. Rio de Janeiro: Imago, 1971.

KLEIN, M. et al. Os progressos da psicanálise. Rio de Janeiro: Zahar, 1982.

LAPLANCHE, J.; PONTALIS, J. B. Vocabulário da psicanálise. 5. ed. Lisboa: Moraes Ed., 1970.

MEJIA-SOTO, G. et al. Morbilidad de los 'niños de la calle'. Adolescencia Latinoamericana, Buenos Aires, v. 1, n. 3, p. 175-182, 1998.

RAPPAPORT, C. R. (Coord.). Temas básicos de psicologia. São Paulo: EPU, 2003.

ROSEN, G. Uma história da saúde pública. São Paulo: Unesp, 1994.

SILVA, M. C. de V. M. TAT: aplicação e interpretação do teste de apercepção temática. São Paulo: EPU, 1989.

SOIFER, R. Psiquiatria infantil operativa. 3. ed. Porto Alegre: Artes Médicas, 1992. v. 1.

WINNICOTT, D. W. Privação e delinqüência. São Paulo: Martins Fontes, 2002. 